\title{
Juridical Review Of The Executorial Strength Of Liability Certificates In Overcoming Non-Loading Loans (Study At Bank Danamon Cab. Sukaramai Assistant)
}

\section{Deri Fachrizal}

Sumatera University Faculty Of Law. E-mail: deri09@gmail.com

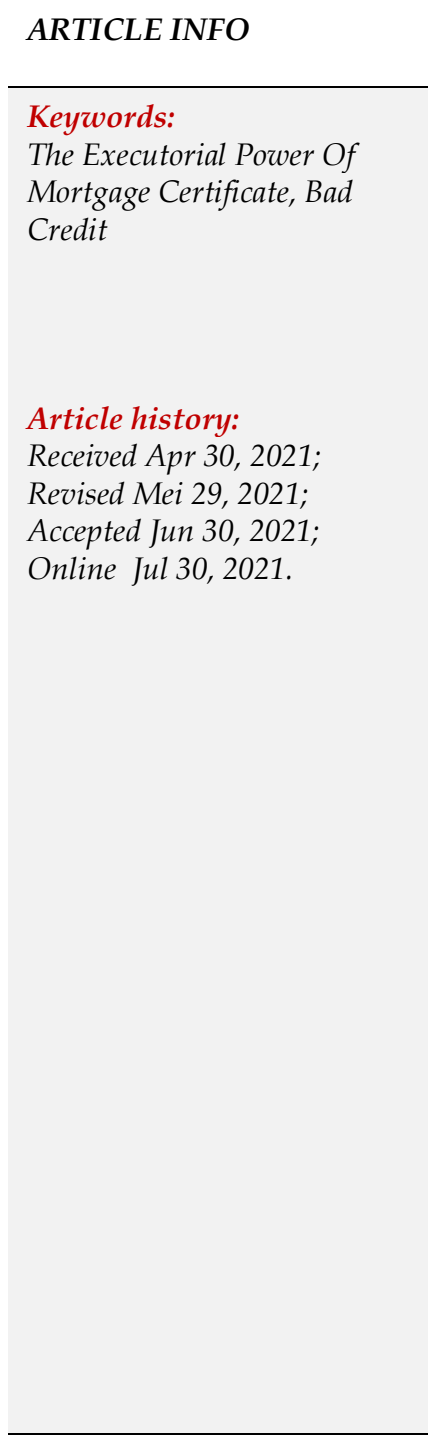
\begin{abstract}
The increase in development activities has resulted in an increasing need for the availability of funds, most of which are obtained through credit activities. So it can be said that credit is one of the most important sources of development financing. Credit in banking activities is the most important business activity, because the largest income from bank business comes from income from credit business activities in the form of interest and fees. The problem in this research is how is the procedure for binding the mortgage certificate as collateral for the credit agreement at PT. Bank Danamon SubBranch Sukaramai Medan. What are the obstacles to Mortgage in Fulfilling the Rights of the Parties in the Mortgage Execution Process at PT. Bank Danamon Sukaramai Medan Sub-Branch and How the Executional Strength of Mortgage Certificate at PT. Bank Danamon Sub-Branch Sukaramai Medan?. The method used in this research is empirical juridical, namely an approach from the point of view of the rules and implementation of regulations that apply in society, which is carried out by researching secondary data first, then continued by conducting research on primary data in the field. The procedures that must be fulfilled by the customer from the time the credit application is submitted until the payment of a loan granted by the Bank is: Credit Application, Credit Investigation and Analysis, Types of Credit. The importance of binding debt guarantees is so that we can anticipate exactly whether the guarantee will be able to be executed or easily executed. This is because the different procedures for binding guarantees have a direct correlation with how they are executed. Obstacles in the Execution of Mortgage as collateral for credit for legal protection for the interests of Creditors. There are several factors that become obstacles that often occur, namely the resistance by the Mortgage holder himself to the execution of the first Mortgage holder's application. This issue is not regulated in UUHT but is in the Material of Civil Procedure Law. The Mortgage Law has given great executorial power to the Mortgage Certificate, namely by the inclusion of an Irah-Irah which reads "For Justice Based on the One Godhead", so that the position of the Mortgage Certificate is the same as the Court's Decision which has obtained permanent legal force.
\end{abstract}

This is an open access article under the CC BY-NC license.

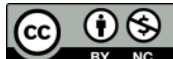

\section{Introduction}

Economic development as part of national development is one of the efforts to realize just and prosperous people's welfare based on Pancasila and the 1945 Constitution. In order to maintain the sustainability of such development, very large funds are needed. Sometimes the funds needed can be met on their own, but sometimes they cannot be met by themselves, so they need 
the help of other parties. Conventionally, the need for funds is provided by financial institutions, among others. This institution has activities in the financial sector that directly or indirectly collect funds and channel them back to the public, in the context of certain financing/investments.

The increase in development activities has resulted in an increasing need for the availability of funds, most of which are obtained through credit activities. So it can be said that credit is one of the most important sources of development financing. Credit in banking activities is the most important business activity, because the largest income from bank business comes from income from credit business activities in the form of interest and fees.

A new credit is launched after there is a written agreement, although it may be in a very simple form between the creditor as the creditor and the debtor as the credit recipient. This written agreement is often referred to as a "credit agreement" (credit agreement, loan, agreement). Law No. 10 of 1998 concerning Amendments to Law no. 7 of 1992 concerning Banking, in Article 1 number (11) what is meant by credit are: "Provision of money or equivalent claims, based on a loan agreement or agreement between a bank and another party that requires the borrower to repay the debt after a certain period of time with interest." An important element in a credit agreement is trust. In addition, another factor that is considered in the credit agreement is what is the guarantee for the credit application. Because, credit that does not have sufficient collateral will contain a large risk. For this reason, in lending activities by banks, there is a need for guarantees from debtors. This is very urgent because the guarantee will be needed if at any time the debtor defaults.

The provision of credit which is the main activity of a bank is often the cause of a bank facing problems. Therefore, efforts to minimize the risk of loss due to non-payment of credit by debtors need to obtain attention which special.To reduce the risk according to the explanation of Law no. 10 of 1998 concerning Amendments to Law no. 7 of 1992 concerning Banking explained that credit guarantees in the sense of confidence in the ability and ability of the debtor to pay off their debts in accordance with the agreement are important factors that must be considered by banks. Therefore, to obtain such confidence, before granting credit, banks must conduct a careful assessment of the debtor's character, ability, capital, collateral, and business prospects. The importance of doing this analysis is to avoid the risk of possible bad credit. In addition, to protect and secure public funds managed by banks and channeled in the form of credit.

The steps taken by banks in securing credit can basically be classified into two. The first is preventive security and the second is repressive security. Preventive safeguards are safeguards that are carried out to prevent credit jams. Meanwhile, repressive safeguards are safeguards carried out to settle loans that have experienced non-performing or congestion (bad loans).Given the importance of the role of credit funds in the development process, it is appropriate for credit providers and recipients as well as other parties involved in credit agreements to obtain protection through a strong guarantee rights institution that can provide legal certainty for all interested parties. In Article 51 of Law no. 5 of 1960 concerning the Basic Regulations on Agrarian Principles (UUPA), has provided a strong guarantee rights institution that can be imposed on land rights called mortgage rights. To fulfill the provisions of Article 51 of the LoGA, on April 9, 1996, Law no. 4 of 1996 concerning Mortgage on land and objects related to land. With the promulgation of Law no. 4 of 1996 concerning Mortgage Rights, In the credit agreement, the debtor does not have the freedom to use his credit according to his own wishes, because as is well known, the purpose of granting credit is to improve the standard of living of the people, so that the use of credit is tied to government programs. It often happens that the use of credit by the debtor turns out to be no longer in accordance with the purpose of providing credit, namely as stated in the agreement credit. In other words, the debtor has misused the credit he received. With the misuse of credit, the bank can determine that the 
debtor has defaulted. One of the characteristics of the mortgage is that it is easy and certain in its execution if the debtor defaults. What is meant by execution in this case is the creditor's effort to enforce his rights by force if the debtor does not voluntarily fulfill his obligations, not only through the implementation of the judge's decision, but also through the implementation of the Grosse Deed and the implementation of decisions from the authorized institution or even the creditor directly. In Article 6 of the Mortgage Law it is stated: "If the debtor is in default, the first mortgage holder has the right to sell the object of the mortgage on his own power through a public auction and take repayment of his receivables from the proceeds of the sale."

\section{Method}

The research method is a scientific method used to obtain data and certain goals. The scientific method means activities based on the scientific method. The scientific method is a combination of rational and empirical approaches. The rational approach provides a coherent and logical framework of thought, while the empirical approach provides a framework for testing to ascertain the truth.

In a scientific way, it is hoped that the data to be obtained is objective, valid, and reliable data. Objective means that everyone will give the same interpretation. Valid means that there is accuracy between the data collected and the data on the actual object. Reliable means the accuracy/consistency/consistency of data obtained from time to time. Research activities are carried out with a specific purpose, and in general that purpose can be grouped into three main things, namely to find, prove, and develop certain knowledge. With these three things, the implications of the research results will be used to understand, solve, and anticipate problems.

\section{Analysis And Results}

3.1 Procedure for Bonding Mortgage Certificates as Collateral for Credit Agreements at Bank Danamon Sub-Branch Sukaramai

\section{a. General Procedures for Granting Credit}

The procedure that must be fulfilled by the customer from the time the credit application is submitted until the payment of a credit granted by the bank is:

1) Credit application.

In principle, the application for credit must be made in a letter addressed to the Head of the Bank.

2) Credit investigation and analysis.

One of the elements and credit is the degree of risk. Therefore, before the credit application is granted, the bank must pay attention to matters relating to the internal condition of the bank and the condition of the prospective customer (borrower).

3) Types of credit.

Credit distribution by type can be divided into 4 (four) namely:

a) Banking credit for the community.

b) Credit seen and the angle of the guarantee.

c) Credit is seen from the point of view of its use.

d) Credit according to how it is used.

e) Credit agreements and credit guarantees.

f) Guarantee binding procedure.

The importance of binding debt guarantees is so that we can anticipate exactly whether the guarantee will be able to be executed or easily executed. This is because the difference in the guarantee binding procedure has a direct correlation with how to execute it. For example, if a fast execution through fiat execution is required, then there is a need for a debt 
acknowledgment bond by a notary, or the making of a mortgage deed. Through these activities, the Bank will see the character of the prospective debtor, information on the prospective debtor's lifestyle, the status of the debtor's residence (own property, parental property, rental house or others). If it is deemed necessary to request additional data in the form of electricity bills, water bills or can also ask for information from neighbors of prospective debtors.

To see business prospects and the ability to pay debts of prospective debtors, it can be done by telephone or through a visit to the prospective debtor's place of business. The bank looks for information about the type of work, salary, position, work experience. Banks must also know the financial condition of the prospective debtor in order to know the ability and method of the prospective debtor in paying off his debts.

b. Mortgage Constraints in Fulfilling the Rights of the Parties in the Mortgage Execution Process at PT. Bank Danamon Sub-Branch Sukaramai

How good a law is, its usefulness for the community will depend on its implementation. Theoretically, UUHT has already regulated explicitly and in detail, but in practice there are still many obstacles to the execution. Of the many applications for execution of mortgages addressed to the Head of the District Court, there are some applications that can be accepted and some cannot be accepted for execution.

This is due to several factors that cause obstacles in the execution of mortgage rights in court and in auction sales, both juridically and non-juridically.Obstacles of mortgage rights in the fulfillment of the rights of the parties in the process of execution of mortgage rights include:

1) Juridical constraints.

There are several factors that become legal obstacles or obstacles that is:

a) There is an explanation of Article 20 paragraph (1) of UUHT which can be concluded that the creditor has the right to take repayment of the guaranteed receivables from the sale of the mortgage object in the event that the proceeds of the sale are greater than the receivables at a maximum value of the mortgage, the rest becomes the rights of the mortgagee. . From this provision, it means that the debt that must be paid from the money from the auction sale of the mortgage object belonging to the debtor is as high as the maximum amount of the mortgage stated in the mortgage certificate. Meanwhile, the creditor usually stipulates an amount greater than what is stated in the mortgage certificate, this is because in the imposition of the mortgage there are conditions, that the debtor as long as the amount depends,

b) Another obstacle is related to the promise contained in Article 11 paragraph (2), namely the promise that the mortgagee will vacate the object of the mortgage at the time of execution of the mortgage. This promise by the creditor is always included in the mortgage certificate, but most debtors will not voluntarily vacate the mortgage object either when the mortgage object is to be executed, before the auction or after the auction is carried out.

c) Another obstacle that often occurs is the resistance by the mortgage holder himself to the execution of the first mortgage holder's application. This issue is not regulated in UUHT but is in the material of civil procedural law.

2) Non-juridical constraints

a) In the execution of mortgages, obstacles often arise beyond prediction, namely the executed parties intentionally mobilize their time to hinder the execution, by mobilizing time to block and block the path and location of the object of execution so that the execution team/executive cannot enter. to the location, as well as obstructing the security forces by burning used car tires and some deliberately getting drunk so as to make the situation noisy and chaotic by shouting and cursing the executioners and 
security forces, so that the situation is not conducive due to the higher number of people. many of the security forces tasked with securing the execution. This situation makes it difficult for executioners and security forces, so that it is clear that the execution cannot be carried out and even has to be postponed, because if the execution is forced or continues to be carried out, the executioner may become a month for the supporters of the executed party. The delay in execution is intended to avoid things that are not desired.

b) Lack of public knowledge about the law so that it is easy to be influenced and provoked by the execution party.

The existing legal provisions, the objection made by the debtor is that it cannot delay the execution of the execution, moreover the execution carried out is based on the executorial power of the mortgage certificate which has the "For the sake of Justice Based on the One Supreme God", which is the same as the court's decision. which has obtained permanent legal force.

\section{c. Executional Strength of Mortgage Certificate at Bank Danamon Sub-Branch Sukaramai}

Talking about execution, like it or not, you have to question the basis for the right to execute it. By talking about it, it must be explained about the existence of an executorial title, in practice the executorial title is often interpreted as an executorial title.

One of the characteristics of a mortgage that is said to be strong is that it is easy and certain in its execution, if the debtor is in default (default) the ease and certainty of the execution can be seen by the provision of easier execution methods than through lawsuits such as ordinary civil cases. Parate execution is also possible in the case of mortgages but there is a difference between parate of mortgage and parate of execution of mortgage. The holder of the mortgage only has the right to parate the execution if it has been previously agreed to do so in the deed of granting the mortgage. While in the mortgage, the right of the mortgage holder to be able to parate execution is a right granted by Article 6 UUHT, in other words it is agreed or not agreed, it is owned by the law by the mortgage holder.

The conditions that must be met by a guarantee so that it can be said to be ideal, which can maximally guarantee the creditor can receive back the money he has lent are as follows:

1) Does not make it difficult for the debtor to carry out his business, thus enabling the debtor to repay his debt;

2) Easy to identify;

3) Any time available for execution;

4) Its value is not easy to decline;

5) Easy to realize so that creditors can receive their funds to pay off debts;

6) It is easy for other parties to know so that no second guarantee is placed on the same collateral except with the knowledge or approval of the guarantee holder;

7) It is not expensive to make and to make it happen.

Article $224 \mathrm{HIR} / 254 \mathrm{RBg}$ in essence are: the following grosse letter from a mortgage deed or debt deed, drawn up before a Notary in Indonesia whose head uses "In the name of Justice" now "For Justice Based on God Almighty" has the same power as the judge's decision. If such a letter is not fulfilled by peaceful means, then the matter of carrying it out is carried out by orders and the leadership of the Head of the District Court, in which the debtor remains silent or stays or chooses his position, namely as stated in the article above in this section, will but with the understanding that bodily coercion is a temporary restraint of freedom against personal selfDebt Insurer or other parties in certain places which according to the provisions laws and regulations applicable must be held responsible. it is only allowed, if it is permitted by the judge's decision. If the matter of carrying out the judge's decision must be carried out in 
whole or in part outside the jurisdiction of the District Court, whose chairman ordered it to be carried out, then the regulations in Article 195 paragraph (2) and subsequent ones, from the provisions of Article $224 \mathrm{HIR} / 258 \mathrm{RBg}$ mentioned above, it turns out, that a grosse of mortgages and debentures made before a Notary in Indonesia has the same force as a judge's decision which already has definite force.

Article $224 \mathrm{HIR} / 258 \mathrm{RBg}$ explains that for the letter that contains the Irah-Irah which reads "In the name of Justice" now "For the sake of Justice Based on the One Godhead" then the letter has the same power as the judge's decision which already has definite/permanent force. And to carry out the execution if it is not fulfilled by peaceful means, then the execution is carried out by orders and the leadership of the Head of the District Court, in which the debtor remains silent or stays or chooses his position.

In the execution of this mortgage object, the creditor does not need to file a lawsuit with the debtor, but it is sufficient to submit a request for execution to the chairman of the court by attaching evidence of the debtor's default which is accompanied by a certificate of mortgage. On that basis, the Chief Justice will issue an execution order and carry out the execution of the mortgage object that is requested for execution.

To carry out an execution with an executorial title, it is sufficient to show evidence that the debtor breaks his promise in fulfilling his obligations, a request for execution by the creditor (the mortgage holder) is submitted to the Head of the District Court, by submitting the certificate of the mortgage concerned as the basis. The execution will be carried out by order and with the leadership of the Head of the District Court, through a public auction conducted by the State Auction Office.

Legal certainty obtained by banks with the enactment of this UUHT is partly because: Mortgage rights give priority to creditors holding mortgage rights. This means that if the debtor defaults, the creditor holding the mortgage can sell through a public auction the land that is used as collateral according to the provisions regulated by UUHT (droit de preference principle); The mortgage will not expire even if the object of the mortgage is transferred to another party for any reason (droit de suite principle); Mortgage certificates have the same executorial power as court decisions that have permanent legal force.

\section{Conclusion}

The procedures that must be fulfilled by the customer from the time a credit application is submitted until the payment of a credit granted by the bank are: credit application, credit investigation and analysis, types of credit. The importance of binding debt guarantees is so that we can anticipate exactly whether the guarantee will be able to be executed or easily executed. This is because the different procedures for binding guarantees have a direct correlation with how to execute them.

Some of the factors that become juridical and non-juridical obstacles are: The explanation of Article 20 paragraph (1) UUHT which can be concluded that the creditor has the right to take repayment of the guaranteed receivables from the sale of the mortgage object in the event that the proceeds of the sale are greater than the receivables maximum of the value of the mortgage, the rest becomes the right of the mortgage giver. Another obstacle is related to the promise contained in Article 11 paragraph (2) j, namely the promise that the mortgage provider will vacate the mortgage object at the time of execution of the mortgage. This kind of promise by the creditor is always included in the mortgage certificate, but most debtors will not voluntarily vacate the mortgage object either when the mortgage object will be executed, before and after the auction. Another obstacle that often occurs is the resistance by the mortgage holder himself 
to the execution of the first mortgage holder's application.

The Mortgage Law has given great executorial power to the Mortgage Certificate, namely by the inclusion of an Irah-Irah which reads "For the sake of Justice Based on the One Godhead", so that the position of the Mortgage Certificate is the same as the Court's Decision which has permanent legal force. . The way to exercise the executorial power possessed by the mortgage certificate is carried out in two ways, namely direct execution based on the provisions of Article 6 of the Mortgage Law and execution through the executorial title regulated in Article 20 paragraph (1) of the Mortgage Law. .

\section{References}

Badrulzaman, Mariam Darus, 1994, Bank Credit Agreement, Bandung: Citra Aditya Bakti.

Djumhana, Muhammad, 2000, Banking Law in Indonesia, Bandung : PT. Image of Aditya Bakti.

Fuady, Munir, 1996, Business Law in Theory and Practice Third Book, Bandung: Citra Aditya Bakti. 2002, Law. Contemporary Credit, PT. Citra Aditya Bakti, Bandung.

Harsono, Boedi, 1997, Agrarian Law: History of the Formation of Basic Agrarian Laws, Content and Implementation, Volume I of National Land Law, Jakarta: Djambatan Publishers.

Hasan, Djuhaendah, 1996, Institute for Material Guarantee for Land and Other Objects Attached to Soil in Conception in the Separation of Horizontal Principles, Bandung; PT. Image of Aditya Bakti.

Halle, 2003, Credit Analysys A Complete Guide, New York: John Wiley and Sons Inc.

Hartono, Sri Rejeki, 2000, Capita Selecta Corporate Law, Mandar Maju, Bandung.

HS Salim, 2004, Development of Guarantee Law in Indonesia, Jakarta: PT. King Grafido Persada.

Harahap, M. Yahya, 2000, Scope of Civil Execution Issues, cet, 1, Jakarta: Sinar Graphic.

HFA, Vollmar, adapted by Alki Chaidir, 1990, , Law of objects according to the Civil Code, Bandung Tasik

Ibrahim, 2004, Cross Default and Cross Collateral As an Effort to Settle Non-performing Loans, Bandung: PT. Aditama Refika.

Kasmir, 2001, Banks and Other Financial Institutions, Jakarta: Raja Grafindo Persada.

Muljono, E. Liliawati 2003, Juridical Review of Law no. 4 of 1996 concerning Mortgage Rights in Relation to the Provision of Credit by Banks, Jakarta: Harwarindo.

Patrik Purwahid Kashadi, 2007, Guarantee Law, Publishing Agency, Faculty of Law Undip.

Poesoko, Herowati 2007, Parate Executie Mortgage Object (Inconsistency, Conflict of Norms and Misguided Reasoning in UUHT), Yogyakarta: Laks Bang Pressindo.

Priyono, Ery Agus, 2004, Semarang Research Methodology Lecture Materials: UNDIP.

2000, Indonesian Agrarian Law, History of the Formation of Basic Agrarian Laws Content and Implementation Jakarta: Djambatan.

Rahman, Hasanuddin, 1996. Legal Aspects of Banking Credit Engagements, Bandung: Citra Aditya bakti, Bandung. 
Rahman, Abdul, 1998, The Fall of Indonesian Banking, SWA Sembada Magazine No. 15/XIV/23 July-5 August

Sutantio, Retnowulan and Iskandar Oeripkartawinata, 1997, Civil Procedure Law in Theory and Practice, Bandung: Mandar Maju.

Subekti, R., 1991, Guarantees for the Provision of Credit According to Indonesian Law, Bandung: Citra AdityBakti.

Soekanto, Soerjono, 1984, Introduction to Legal Research Jakarta: UI-Press. Sutojo, Siswanto, 2007, The Management of Commercial Bank, Jakarta: Damar Noble Libraries.

Sjahdeini, Sutan Remy, 1999, Mortgage Asaz-Asaz, Main Provisions and Problems Faced by Banking A Study on Mortgage Law), Bandung: Alumni.

Sudrajat, Sutardja, 1997, Registration of Mortgage Rights and Issuance of Certificates, Bandung: Mandar Maju.

Suyatno, Thomas, et al., 1992, Fundamentals of Credit. Gramedia Pustaka Utama, Jakarta.

Usman, Racmadi, 2008, Civil Guarantee Law, First Edition Jakarta : PT Sinar Graphica. 